\title{
The Effect of Reciprocal Teaching on Social Science Elementary Problem Solving Skills
}

\author{
Diyas Age Larasati \\ Primary School Teacher Education Study Program Faculty of Languages and Science \\ Universitas Wijaya Kusuma Surabaya \\ larasati_age@yahoo.co.id
}

\begin{abstract}
The purpose of this study was to determine the effect of reciprocal teaching on IPS elementary problem solving skills. This research method was quasi-experimental using two randomized control group pretest-posttest design. Two classes were chosen, namely the experimental class by applying the reciprocal teaching approach and the control class using the lecture and discussion approach. The population of this research is class IV SDN Pakis V Surabaya, with sample class IV-A as the experimental class and class IV-B as the control class. Each class has 35 students. The instruments of this study used tests of problem solving abilities, observation sheets, and documentation. Essay-type problem ability tests with 5-item questions. Before being tested in research, the problem is firstly tested based on the level of validity, level of difficulty, different power, and reliability. The analysis technique in this study uses the $t$ test formula with the help of SPSS 25.0 for window. Significant level $\alpha=95 \%$. $\mathrm{H}_{0}$ is accepted if $\mathrm{t}_{\text {arithmetic }}<\mathrm{t}$ table, and $\mathrm{H}_{0}$ is rejected if $\mathrm{t}_{\text {arithmetic }}>\mathrm{t}_{\text {table. }}$. And $\mathrm{H}_{1}$ is accepted if the significant value $<0.05$ and $t_{\text {arithmetic }}>t_{\text {table. }}$. The results of the analysis of research data through the $t$ test, showed a significant number of 0.01 . This shows that $\mathrm{H}_{0}$ is rejected and $\mathrm{H}_{1}$ is accepted because significant values of $0.01<0.05$ and $12.705>t$ table 1.697 . The results of the analysis indicate that there is an effect of reciprocal teaching on the ability to solve social studies in elementary school. Keywords: Reciprocal Teaching, Problem Solving Ability, IPS
\end{abstract}

\begin{abstract}
Abstrak. Tujuan penelitian ini untuk mengetahui pengaruh reciprocal teaching terhadap kemampuan pemecahan masalah IPS SD. Metode penelitian ini kuasi eksperimen dengan menggunakan two randomized control group pretes-posttest design. Dipilih secara acara dua kelas, yaitu kelas eksperimen dengan menerapkan pendekatan reciprocal teaching dan kelas kontrol dengan menggunakan pendekatan ceramah dan diskusi. Populasi penelitian ini kelas IV SDN Pakis V Surabaya, dengan sampel Kelas IV-A sebagai kelas eksperimen dan kelas IV-B sebagai kelas kontrol. Masing-masing kelas berjumlah 35 siswa. Intrumen penelitian ini menggunakan tes kemampuan pemecahan masalah, lembar observasi, dan dokumentasi. Tes kemampuan masalah berjenis esai dengan 5 butir soal. Sebelum diujikan dalam penelitian, terlebih dahulu soal tersebut diuji berdasarkan tingkat validitas, tingkat kesukaran, daya beda, dan reliabilitas. Teknik analisis dalam penelitian ini menggunakan rumus uji t dengan bantuan SPSS 25.0 for window. Tingkat signifikan $\alpha=95 \% . \mathrm{H}_{0}$ diterima apabila $\mathrm{t}_{\text {hitung }}<\mathrm{t}_{\text {tabel }}$, dan $\mathrm{H}_{0}$ ditolak apabila $\mathrm{t}_{\text {hitung }}>\mathrm{t}_{\text {tabel. }}$. Dan $\mathrm{H}_{1}$ diterima apabila nilai siginifikan $<0,05$ dan $\mathrm{t}_{\text {hitung }}>\mathrm{t}_{\text {table }}$. Hasil analisis data penelitian melalui uji t, menunjukkan angka signifikan sebesar 0,01 . Hal tersebut menunjukkan bahwa $\mathrm{H}_{0}$ ditolak dan $\mathrm{H}_{1}$ diterima karena nilai signifikan $0,01<0,05$ dan 12,705>t tabel 1,697. Hasil analisis tersebut menunjukkan
\end{abstract}

Kata Kunci: Reciprocal Teaching, Kemampuan Pemecahan Masalah, IPS 


\section{INTRODUCTION}

Education has an important role in improving the quality of human resources. In line with Nur \& Sudarsono (2018) Education, today must be able to function in building the capacity of the nation as a human being learner, so that they can be reliable and confident in current global regulations and design into the future. Students are equipped with knowledge, attitudes, and skills to face future global challenges. Among them to realize this through the application of learning approaches, namely the reciprocal teaching approach.

Reciprocal teaching is a constructivist approach aimed at making students able to master learning well by using four cognitive approaches, namely clarifying, predicting, making questions, and summarizing material that focuses on the collaboration of fellow students in small groups and in large groups which involve the teacher with students (Sugandi, 2019). Reciprocal teaching approaches include constructive learning. Reciprocal teaching stages construct or build students' knowledge based on what they have learned. The construction of student knowledge is manifested in questions.

Reciprocal teaching approach is one approach that has benefits so that learning objectives are achieved through independent learning activities and students are able to explain their findings to other parties (Ayu, 2016). Reciprocal teaching-learning trains students to learn the material first independently. Then students are required to explain it to their friends. Students play an active role during reciprocal teachinglearning. Students summarize the material that has been learned, construct thinking by asking questions, confirming, and predicting it. The reciprocal teaching approach to the teacher acts as a facilitator and guide only. The teacher chooses the learning model and provides media and learning material. The teacher also guides students to clarify if there is a concept and explains again if there are students who do not understand.

According to Syamsiani (2018) that the advantages of a reciprocal teaching approach, in general, can be formulated as follows (1) Improving learning outcomes of problemsolving skills, metacognitive skills, reading comprehension, and conceptual understanding, (2) increasing the understanding of independent learning, motivating learning and collaboration in groups, (3) improve communication skills and express opinions, (4) Avoid boredom or boredom in learning, (5) increase sense of responsibility in learning. Based on Syamsiani's opinion, the reciprocal teaching approach is in accordance with the current educational challenges, namely having the advantage to train students to think at a higher level. High-level thinking in reciprocal teaching-learning is problem-solving skills. The reciprocal teaching approach also trains 
students to communicate well to explain their understanding to their peers. Students also feel happy learning, because they can learn independently individually or in groups. Students do not feel bored during reciprocal teaching-learning so that it can motivate student learning.

One ability that needs to be honed in elementary education is the ability to solve problems (Masfuah \& Pratiwi, 2013). Students need for problem-solving skills to obtain results that will be obtained in a problem (Tan, 2019). Students always face problems in their daily lives. Effective and efficient problem solving requires problem-solving abilities. Based on this, the problem-solving ability needs to be applied at the elementary level, namely Elementary Schools. The ability to think highly, especially problem solving, requires a continuous training process.

Problem-solving skills are useful to equip students to find problem-solving and be able to apply it in everyday life. In line with Handayani (2017) Problem-solving ability is an ability that a person must have to carry on his life because in everyday life many situations are found which examples of problem-solving situations are. Problemsolving abilities are applied in social studies learning.

Social Sciences (IPS) is the study of a set of events, facts, concepts, and generalizations related to social issues whose material is taken from various social sciences, such as geography, history, economics, anthropology, sociology, politics, and psychology and is packaged scientifically to provide insight and deep understanding to students, especially at the elementary and secondary levels (Made, Wardani, Suniasih, \& Sujana, 2019). Social Sciences (IPS) includes multidisciplinary science that is presented contextually in the form of events, facts, and social problems that exist in the environment around students. Social studies that are in direct contact with students' social lives need to be designed in such a way as to form personalities that are characterized by sustaining social experiences to build their potential (Kanji, Nursalam, Nawir, \& Suardi, 2019).

This research uses social resource IPS material and its utilization. Students need to understand the natural resources in Indonesia and how they are used. Exploited natural resources will lead to new problems and can lead to natural disasters. Presentation of problems in learning in the classroom, students are expected to be able to understand the causes and consequences of natural resources that are exploited continuously without thinking long term. This encourages students to look for solutions to their problems. Social studies learning students can practice problemsolving skills. Social studies have an important role in practising problem-solving skills. Social studies play an important role in students' social interactions. To form 
characters at developing the potential that is beneficial to themselves, society, nation and country (Kanji, Nursalam, Nawir, \& Suardi, 2020).

Problems in social studies learning results are low, students feel bored and not enthusiastic about learning. Social studies learning is also considered to be a subject full of theory and memorization only, so students are less interested in learning it. The reason is that the teacher delivers the material monotonously through lectures, and students are only as listeners. Teachers also still apply low-level thinking or memorization, so learning is less meaningful for students (Larasati, 2020b). The teacher is not accustomed to practising higher-order thinking skills, especially problem-solving skills. This resulted in students not being able to solve problems effectively and efficiently. These problems indicate that social studies learning is not under its objectives.

The purpose of social studies at elementary school is to prepare students as citizens who have knowledge, skills, attitudes and values that can be used as a means to solve personal or social problems in order to become a state citizen. Good (Syamsiani, 2018). Social studies learning not only equips students with knowledge but also the ability to solve problems. This problem-solving ability is a provision for students to face and solve life problems. According to Larasati (2020) Social Studies learning in elementary schools is able to condition the effort to equip basic skills for students to become human beings and good citizens. Social studies learning is meaningful learning for students and long-life learning.

These problems are the background of this research. The purpose of this study was to determine the effect of the reciprocal teaching approach to the ability to solve social studies in elementary school.

\section{RESEARCH METHODS}

This research approach was quantitative with a quasi-experimental design. The design used in this study was the two randomized control group pretest-posttest design. There were two groups determined randomly, the experimental and control groups. The pre-test was given by both groups before the research was conducted, and post-test was given by both groups after the research was done. The experimental group was treated using the reciprocal teaching approach and the control group applied the conventional approach. A more detailed explanation could be seen in Table below:

Table 1 .The research design

\begin{tabular}{llll}
\hline Group & $\begin{array}{l}\text { Pre- } \\
\text { test }\end{array}$ & Treatment & Post-test \\
\hline Experiment & $\mathrm{O} 1$ & $\mathrm{X} 1$ & $\mathrm{O} 2$ \\
Control & $\mathrm{O} 1$ & $\mathrm{X} 2$ & $\mathrm{O} 2$ \\
\hline
\end{tabular}

Where:

O1 : pre-test

O2 : post-test

$\mathrm{X} 1$ : Using reciprocal teaching

$\mathrm{X} 2$ : Using conventional approach 
The location of this research is at SDN Pakis V Surabaya. The school is located on Pakis Sidokumpu Street, Pakis, Sawahan District, Surabaya City, East Java. The location was chosen because it is close to the researcher. The independent variable in this study is the reciprocal teaching approach. The dependent variable is a problem-solving ability.

This research was conducted in the first and second week of October 2019. The population of this research is fourth-grade students in Odd semester of the 2019-2020 school year. The research sample was chosen using random sampling and 2 classes were chosen randomly. Class IV-A totalled 35 students as the experimental class and class IV B totalled 35 students as the control class.

This research instrument used tests, observations, and documentation. The test in this research was essay type with the number of 5 items. The test was carried out on the experimental and control class. Tests given before the study (pre-test) with the aim of obtaining preliminary data on problem-solving abilities. And tests given after research (posttest) with the aim of obtaining final data on problem-solving abilities. The experimental and control classes were given the same pretest and post-test and the results of their processing to test the research hypothesis.

The observations of this research were observation sheets for students. Observer gives a checkmark $(\sqrt{ })$ on the observation sheet. The documentation of this research is in the form of written documents and drawings. The documentation in this study was used to obtain data from SDN Pakis V Surabaya regarding the names of students, and the values for determining the research sample.

The test used in this study was previously tested instrument first. The test instruments of this study include tests of validity, level of difficulty, different power, and reliability. The following is a detailed explanation. The level of validity of each item is done by comparing $r$ results with $r$ tables. $R$ results for each item can be seen in the corrected item-total correlation while the $r$ table can be seen in the following Table 2. Validity Criteria

\begin{tabular}{cl}
\hline Correlation coefficient & \multicolumn{1}{c}{ Classification } \\
\hline $0,800-1,000$ & Very valid \\
$0,600-0,799$ & Valid \\
$0,400-0,599$ & enough valid \\
$0,200-0,399$ & Less valid \\
$0,000-0,199$ & Not valid \\
\hline
\end{tabular}

The formula used was as follows:

$$
\mathrm{TK}=\frac{\sum \mathrm{s}}{\mathrm{n}} \times 100 \%
$$

Where:

TK $=$ Difficulty Level

$\sum \mathrm{s}=$ Incorrect

The calculation results of the difficulty level on each item then classified according to the criteria in Table 3 as follows. 
Table 3. Difficulty Level Criteria

\begin{tabular}{cc}
\hline Criteria & Classification \\
\hline $0-<25 \%$ & Difficult \\
$25-75 \%$ & average \\
$>75 \%$ & Easy \\
\hline Source: Purwanto, 2005
\end{tabular}

Source: Purwanto, 2005

The method of analysing different power was using a sample method by taking $27 \%$ from the upper group, and $27 \%$ from the lower group from the entire population, then calculated using the following formula.

$$
\mathrm{DB}=\frac{\sum \mathrm{Skb}-\sum \mathrm{Ska}}{\frac{1}{2} \mathrm{Sm}(\mathrm{nka}+\mathrm{nkb})}
$$

Keterangan:

DB = Discriminating Power

$\sum$ Ska $=$ number of errors of the upper group

$\sum \mathrm{Skb}=$ Number of error lower group

$\mathrm{Sm}=$ Number of error lower group

nka $=$ Number of students of the upper

grup

$\mathrm{nkb}=$ Number of students lower Group

The results of the calculation of the different power of each item items then classified according to the criteria in Table 4 as follows.

Table 4 The criteria of Discrimating Power

\begin{tabular}{cc}
\hline Criteria & Classification \\
\hline $0,7-1,00$ & Very Good \\
$0,40-0,69$ & Good \\
$0,20-0,39$ & satisfactory \\
$0,00-0,19$ & poor \\
Negative Value & Very Poor \\
\hline
\end{tabular}

Source: Purwanto, 2005

The reliability test of essay questions in this study uses Cronbach Alpha analysis through the SPSS 25.00 for windows program. The reliability level of the instrument adjusted for the reliability criteria can be seen in Table 5 as follows.

Table 5.Reliabilty Criteria

\begin{tabular}{cc}
\hline Reliability Interval Score & Criteria \\
\hline $0,800-1,000$ & Very reliable \\
$0,600-0,799$ & Reliable \\
$0,400-0,599$ & Moderate \\
$0,200-0,399$ & Low reliable \\
$0,000-0,199$ & Not reliable \\
\hline
\end{tabular}

Source: Purwanto, 2005

This study tested the hypothesis by $\mathrm{t}$ test using SPSS 25.0 for window. Significant level $\alpha=95 \%$. H0 is accepted T-Test $<\mathrm{t}$ table, and $\mathrm{H} 0$ is rejected T-Test> T Table. And $\mathrm{H} 1$ is accepted if the significant value $<0.05$ and T-Test > T Table.

\section{DISCUSSION}

He problem-solving ability test that will be used for this research was tried out beforehand. The test instruments include validity, difficulty level, difference power, and reliability. The results of the trial can be seen in Figure 1.1 below.

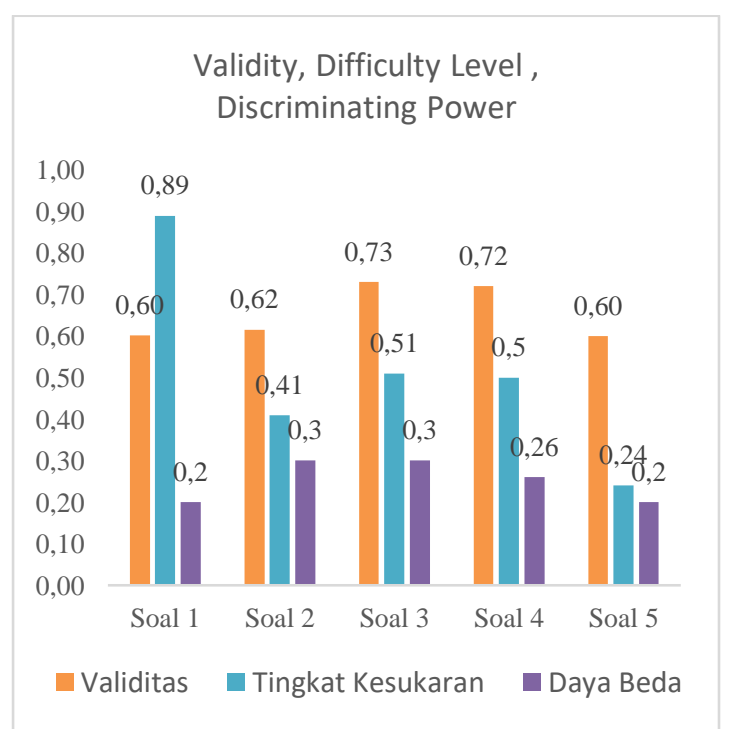


Figure 1.The Result of Validity, Difficulty Level and Discriminating Power of item

Based on the picture above, it shows that the question number 1 has valid criteria of 0.60 , the difficulty level of the easy criteria is 0.89 , and the difference in power is enough sufficient of 0.2. Problem number 2 to number 4 are valid criteria, the level of difficulty is average, and the power difference is sufficient. Problem number 5 has a validity of 0.6 with valid criteria, a difficulty level of 0.24 with difficult criteria, and a difference of 0.2 with sufficient criteria. Reliability as large as 0.75 has good criteria (reliable). In conclusion, this problem-solving ability test can be used as a tool to test this study without any revisions.

There are 4 stages in the reciprocal teaching approach in this study, namely summarizing, asking questions, confirming, and predicting. The implementation of the reciprocal teaching approach in the experimental class is recorded in the observation sheet. The results of observing the reciprocal teaching approach can be seen in Figure 1.2 below.

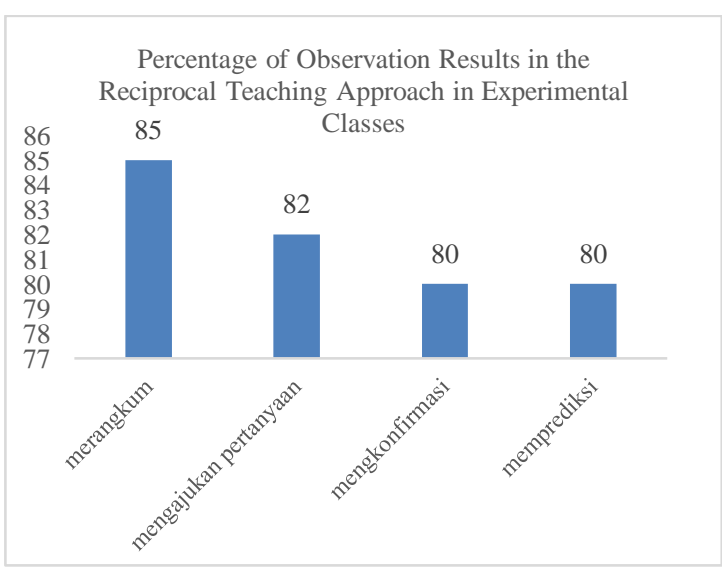

Figure 2. Percentage of Observation Results in the Reciprocal Teaching Approach in Experimental Classes

Based on the percentage of observations in the experimental class by applying the reciprocal teaching approach shows a high percentage. Students play an active role in each stage of the reciprocal teaching approach. There are 4 stages of reciprocal teaching in this study, namely summarizing $85 \%$, asking questions $82 \%$ and confirming and predicting $80 \%$ each. Students are not accustomed to the confirmation and prediction stages, so their grades are lower than the stages of summarizing and asking questions.

Indicators of problem-solving ability in this study include understanding, planning, solving, and reviewing. The achievement of indicators of the results of problem-solving abilities in the experimental and control classes can be presented in Figure 1.3 as follows.

Figure 3: The Achievement Percentage of Problem Solving Indicators

The Achievement Percentage of Problem Solving Indicators

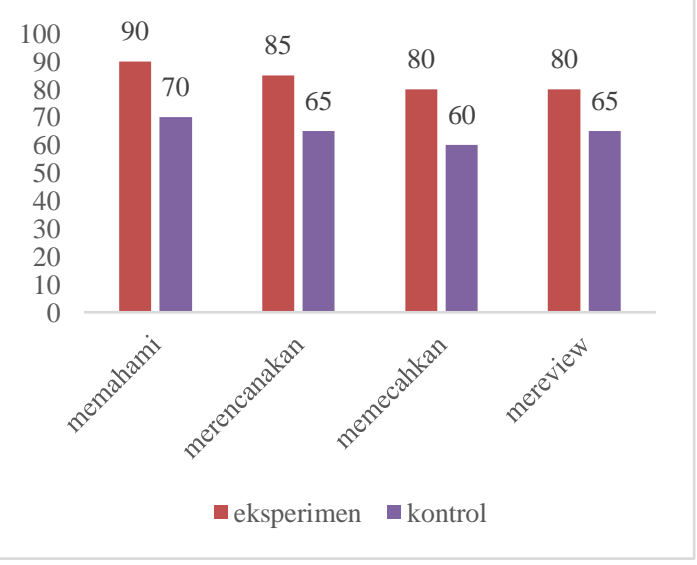


Based on the achievement of overall problem-solving indicators, the experimental class is higher than the control class. The average achievement of all indicators of problem-solving in the experimental class was $83.75 \%$. While the control class average achievement of all indicators of problemsolving by $65 \%$. This can show that the experimental class was $18.75 \%$ higher than the control class. The application of the reciprocal teaching approach is better than applying the teacher, discussion and assignment approach in achieving problem-solving abilities. It can also be shown in the acquisition of the average pre-test and post-test value of the experimental class is higher than the control. More details can be seen in Table 6 below.

Table 6 Pretest and Posttest score in the experimental and control class

\begin{tabular}{ccccccc}
\hline Test & \multicolumn{3}{c}{ Experiment } & \multicolumn{3}{c}{ Control } \\
\cline { 2 - 7 } & $\mathrm{N}$ & $\mathrm{X}$ & $\mathrm{S}$ & $\mathrm{N}$ & $\mathrm{X}$ & $\mathrm{S}$ \\
Pretest & 35 & 44,03 & 14,03 & 35 & 38,35 & 12,68 \\
posttest & 35 & 81,81 & 15,55 & 35 & 63,61 & 12,28 \\
\hline
\end{tabular}

Based on the average pre-test score there was an increase of 5.68. The average pretest score in the experimental class was 44.03 and the control was 38.35 . The average posttest score of the experimental class was 81.81 and the control was 63.61. This shows that the average post-test score was higher with a difference of 18.2. There was a significant increase of 37.78 in the experimental class from pre-test of 44.03 to post-test of 81.81 .
While the control class from pre-test was 38.35 to post-test 63.61, an increase of 25.26.

The results of the analysis of research data through the t-test showed a significant number of 0.01 . This shows that $\mathrm{H} 0$ is rejected because the significant value of $0.01<0.05$ and $t$ arithmetic of 12.705 is greater than $t$ table of 1.697. And $\mathrm{H} 1$ is accepted because of the significant value of $0.01<0.05$ and $12.705>t$ table 1.697. The results of the analysis indicate that there is an effect of reciprocal teaching on the ability to solve social studies in elementary school.

The results of this study indicate that there is an increase in students' social problemsolving skills applying a reciprocal teaching approach better than students applying a conventional approach. The reciprocal teaching approach has a positive effect on students because during learning students feel happy. During treatment, students are very enthusiastic in learning to use reciprocal teaching strategies (Sriyani Ketong, Burhanuddin, 2018). Learning that is fun and does not burden students will provide meaningful learning. The reciprocal teaching approach is more effective than the lecture and discussion approach in terms of problemsolving skills. As for the background to the improvement of problem-solving abilities, it is caused by the stages in the reciprocal teaching approach in line with indicators of problemsolving ability. The stages of the reciprocal teaching approach are the stages of 
summarizing, students independently note the important points of the material presented by the teacher namely natural resources and their utilization. Independent characters, students do learning activities independently in class if they are doing independent assignments from the teacher (Kanji et al., 2020). At this stage, students play an active role to explain important points that have been recorded using their language. In line with research (Ramadhani, 2019) The application of the reciprocal teaching-learning model makes students not passively accept the material presented but is also active in constructing or constructing their knowledge, so learning will be more meaningful and more remembered by students. The ability to communicate to share material with friends becomes a new experience for students. This is in accordance with indicators of problem-solving ability: understanding.

Stages of asking questions, at this stage students are tasked with asking questions related to natural resource material and its use. The teacher guides students to use questions ranging from low to high levels. Students prepare themselves to communicate with their classmates, so they can ask questions creatively. This is in accordance with indicators of problem solving ability: planning. Each group and even individuals have an active role in the activity of asking questions, giving rise to two-way communication. The learning becomes livelier and not boring, so students are motivated to contribute asking questions.

The next stage is to confirm, at this stage the student is tasked with confirming by reexplaining the knowledge and information obtained, so that students master the concepts they have learned. Students creatively find problems in natural resources and their use. From these problems, students make observations to solve problems with new innovations. Problem solving that is confirmed by students is not only a concept, but can be applied in everyday life. In line with Ramadhani's research (2019), the Reciprocal Teaching Approach is a new concept in learning that can design students to learn independently, be creative, and be more active in participating in learning activities, and can also help solve the needs often faced in using old learning models. Stages confirm in accordance with indicators of problem solving: problem solving.

The last stage is predicting, students are tasked with helping the group to link the material of natural resources and their utilization by presenting predictions. Students can describe ideas according to their understanding. Activity predicts in accordance with indicators of problem solving: reviewing. the student acts as the teacher delivering the predicted results obtained by his group to be studied together so that students can construct their knowledge (Nurhasanah, 2019). 
Based on the findings in this study there are several obstacles, namely limited time, lack of preparation of teachers and students are still shy and not accustomed to conveying their understanding to their peers. These obstacles can be overcome by the teacher being able to manage time management, so that all stages of the reciprocal teaching approach can be implemented to the maximum. The teacher prepares the learning equipment carefully by preparing lesson plans, and preparing the learning materials and media needed. The teacher applies a learning method or model that activates students, so students are accustomed to learning independently and confidently.

\section{CONCLUSION}

The results of this study have the effect of reciprocal teaching on IPS elementary problem solving skills. It is shown from $\mathrm{H} 0$ rejected, and $\mathrm{H} 1$ accepted with a significance value of $0.01<0.05$ and $t$ test $12.705>t$ table 1.697. The reciprocal teaching approach can improve problem solving skills, because the reciprocal teaching approach stages are in line with the problem solving indicators. This study also finds the obstacles in the reciprocal teaching approach which are limited time, lack of teacher preparation, and students are still shy in asking and expressing opinions to their peers.

\section{REFERENCES}

[1] Ayu, S. M. (2016). Penerapan Model
Pembelajaran Reciprocal Teaching Untuk Meningkatkan Keaktifan Siswa Dalam Proses Pembelajaran. Seminar Nasional Pendidikan (SNP) 2016, ISSN: 2503-4855, 105-110. Retrieved from https://publikasiilmiah.ums.ac.id/bitstream/h andle/11617/7276/artikel 11.pdf? sequence $=1$ \&isAllowed $=\mathrm{y}$

[2] Handayani, D. (2017). Pengaruh Model Problem Based Learning Terhadap Kemampuan Pemecahan Masalah Matematis Siswa Di Kelas VIII MTs. S AL-Washliyah Tahun ajaran 2016/2017. Universitas islam Negeri Sumatera Utara. Retrieved from http://repository.uinsu.ac.id/3121/1/PDF.pdf

[3] Kanji, H., Nursalam, Nawir, M., \& Suardi. (2019). Evaluasi Integrasi Pendidikan Karakter dalam Pembelajaran Ilmu Pengetahuan Sosial di Sekolah Dasar. JED (Jurnal Etika Demokrasi) Pendidikan Pancasila Dan Kewarganegaraan, 4(2), 56$63 . \quad$ https://doi.org/ht https://doi.org/10.26618/jed.v4i2.2386

[4] Kanji, H., Nursalam, Nawir, M., \& Suardi. (2020). Supporting and Inhibiting Factors of Character Education in Learning Social Studies at Primary Schools. JED (Jurnal Etika Demokrasi) Pendidikan Pancasila Dan Kewarganegaraan, 5(1), 1-14. https://doi.org/https://doi.org/10.26618/jed.v $5 \mathrm{i} 1.2966$

[5] Larasati, D. A. (2020a). Pengaruh Media Peta Berbasis Konstruktivistik Terhadap Hasil Belajar IPS Siswa Sekolah Dasar. Jurnal Elementaria Edukasia, 3(1), 73-83. https://doi.org/http http://dx.doi.org/10.31949/jee.v3i1.2091

[6] Larasati, D. A. (2020b). Pengaruh Model Discovery Learning Berbasis Higher Order Thinking Skill Terhadap Kemampuan Berpikir Kritis. VOX Edukasi: Jurnal Ilmiah Ilmu Pendidikan, $11(1), \quad 39-47$. https://doi.org/10.31932/ve.v11i1.684

[7] Made, N., Wardani, A., Suniasih, N. W., \& Sujana, W. (2019). Korelasi Antara Konsep Diri dengan Kemampuan Pemecahan Masalah IPS. TSCJ, 2(1), 37-46.

[8] Masfuah, S., \& Pratiwi, I. A. (2013). Peningkatan Kemampuan Pemecahan 
Masalah Siswa Melalui Pembelajaran Problem Based Learning Berbasis Socio Scientific Issues. Edukasi, 10(2), 179-190.

[9] Nur, S., \& Sudarsono. (2018). Implementasi Pendidikan Demokrasi Dalam Pembelajaran IPS Study Kasus SMA Negeri 6 Takalar. Equilibrium: Jurnal Pendidikan Sosiologi, VI(1), 95-103.

[10] Nurhasanah, N. (2019). Pengaruh Pembelajaran Matematika Dengan Menggunakan Model Reciprocal Teaching Terhadap Kemampuan Pemecahan Masalah Matematik Peserta Didik (Penelitian Terhadap Peserta Didik Kelas VII MTS Bahrul Ulum Tasikmalaya Tahun Pelajaran 2013/2014). In Prosiding Seminar Nasional \& Call For Papers 2019 (pp. 457-462). Retrieved from http://jurnal.unsil.ac.id/index.php/sncp/article /view/1077

[11] Purwanto, Edi. (2005). Evaluasi Hasil Belajar Bidang Studi Pendidikan Geografi. Malang: UMPress.

[12] Ramadhani, S. W. S. dan S. (2019). Penerapan Model Pembelajaran Reciprocal Teaching untuk Meningkatkan Kemampuan Pemecahan Masalah Matematis Siswa. UNION: Jurnal Pendidikan Matematika, 7(2), 263-273. https://doi.org/http://dx.doi.org/10.30738/uni on.v7i2.4539

[13] Sriyani Ketong, Burhanuddin, dan W. K. A. (2018). Keefektifan Model Pembelajaran Reciprocal Teaching Dalam Kemampuan Membaca Memahami Siswa Kelas XI IPA SMA Negeri 11 Makassar. Eralingua: Jurnal Pendidikan Bahasa Asing Dan Sastra, 2(1), 45-54.

[14] Sugandi, A. I. (2019). Penerapan Reciprocal Teaching Terhadap Kemampuan Berpikir Kreatif dan Self Concept Matematik Siswa SMP. Jurnal Analisa, 5(2), 161-170. https://doi.org/10.15575/ja.v5i2.6350

[15] Syamsiani. (2018). Pengaruh Pembelajaran Reciprocal Teaching Berbantu Peta Pikiran Terhadap Hasil Belajar Dan Kemampuan Menulis Artikel Dalam Pembelajaran IPS Siswa Kelas VI SDN 1 Dadaprejo Kota Batu Provinsi Jawa Timur. Universitas Islam
Negeri Maulana Malik Ibrahim Malang. Retrieved from http://etheses.uinmalang.ac.id/12135/1/15761010.pdf

[16] Tan, H. (2019). Kemampuan Pemecahan Masalah Matematika. Retrieved from https://www.researchgate.net/publication/333 089920_kemampuan_pemecahan_masalah_ matematika 